Article

\title{
One-Dimensional and Three-Dimensional Numerical Investigations of Thermal Performance of Phase Change Materials in a Lithium-Ion Battery
}

\author{
Van-Tinh Huynh, Kyoungsik Chang $\mathbb{D}$ and Sang-Wook Lee * \\ Department of Mechanical Engineering, University of Ulsan, Ulsan 44610, Korea; hvtinh97@gmail.com (V.-T.H.); \\ kschang76@ulsan.ac.kr (K.C.) \\ * Correspondence: leesw@ulsan.ac.kr
}

Citation: Huynh, V.-T.; Chang, K.; Lee, S.-W. One-Dimensional and Three-Dimensional Numerical Investigations of Thermal Performance of Phase Change Materials in a Lithium-Ion Battery. Energies 2021, 14, 8386. https:// doi.org/10.3390/en14248386

Academic Editor: Calin Iclodean

Received: 20 October 2021

Accepted: 8 December 2021

Published: 13 December 2021

Publisher's Note: MDPI stays neutral with regard to jurisdictional claims in published maps and institutional affiliations.

Copyright: (c) 2021 by the authors. Licensee MDPI, Basel, Switzerland. This article is an open access article distributed under the terms and conditions of the Creative Commons Attribution (CC BY) license (https:/ / creativecommons.org/licenses/by/ $4.0 /)$.

\begin{abstract}
The thermal performance of a large-format (52.3 Ah) Li-ion pouch battery with an noctadecane PCM was investigated. A simplified 1D model was employed to estimate the transient thermal behavior. Two design parameters, the thickness and the thermal conductivity of the PCM, were considered. A $0.5 \mathrm{~mm}$ thick n-octadecane $\mathrm{PCM}$ integrated with aluminum foam reduced the battery temperature to $34.3^{\circ} \mathrm{C}$ and $50.7^{\circ} \mathrm{C}$ at the end stage of discharging under $3 \mathrm{C}$ and $5 \mathrm{C}$ discharge rates, respectively. The $1 \mathrm{D}$ results compared to the $3 \mathrm{D}$ results were able to predict the temperature dissipation by the PCM method at the end of discharging. The 1D approach clearly produced reliable results in predicting the thermal behavior of the PCM cooling and was superior in practical applications with its low cost and time consumption. A 3D CFD simulation was able to describe the detailed temperature uniformity in the cell, which is an important factor in the design and evaluation of a battery cooling system.
\end{abstract}

Keywords: lithium-ion battery; phase change material; large-format cell; electric vehicle

\section{Introduction}

Energy storage systems, such as fuel cells, batteries, flywheels, and ultracapacitors, play important roles in pure electric vehicles and the hybrid electric vehicle industry. There are currently three leading types of batteries in the market: Li-ion, nickel-metal hydride, and lead-acid. The Li-ion battery is a promising candidate with outstanding features, including a low self-discharge rate, high specific energy, and fast charging capacity without a memory effect [1]. However, the internal electrochemical reactions and resistances in its cells produce a considerable amount of heat. This results in fairly high and non-uniform cell temperatures when it is charged and discharged. The optimal operating temperature of a Li-ion battery ranges from $25{ }^{\circ} \mathrm{C}$ to $40{ }^{\circ} \mathrm{C}$ [2]. In addition, the maximum temperature difference within a cell should be less than $5^{\circ} \mathrm{C}$ to maintain a balance between its life cycle and efficiency [3]. When the maximum temperature is higher than $80^{\circ} \mathrm{C}$, thermal runaway could happen and exothermic reactions will occur, eventually leading to catastrophic results [4].

Various thermal management strategies have been proposed, which can be classified into the active (air and liquid cooling), passive (phase change material (PCM) cooling and heat pipes), and hybrid methods. Chen et al. [5] optimized the distance between cells to improve the air cooling performance, whereby the maximum temperature of the battery pack was decreased by $4 \mathrm{~K}$ and the maximum temperature difference was decreased by $69 \%$. Under uphill conditions (high heat generation and/or a high discharge rate), liquid cooling may be required to sufficiently dissipate the thermal energy. Shang et al. [6] achieved the best performance of liquid cooling when the width of the cooling plate was $70 \mathrm{~mm}$, the inlet had a temperature of $18^{\circ} \mathrm{C}$, and the mass flow rate was $0.21 \mathrm{~kg} / \mathrm{s}$. In that setup, the 
maximum temperature was decreased by $12.61 \%$ and the temperature uniformity was increased by $20.83 \%$.

PCMs have been shown to greatly improve the temperature uniformity of Li-ion batteries. Wang et al. [7] showed that the melting process can be sped up by using a paraffin/aluminum foam composite. Compared with pure paraffin, the heat storage time of that composite PCM was $74.4 \%$ when the heat flux was $12,000 \mathrm{~W} / \mathrm{m}^{2}$. Jilte et al. [8] proposed the best design with seven cells, seven primary containers, and one secondary container. At the environment temperature of $40{ }^{\circ} \mathrm{C}$, the use of a nanoparticle-enhanced PCM (nePCM) can reduce the temperature of a cell to under $46{ }^{\circ} \mathrm{C}$ with the effect of natural convection.

Heat pipes are employed as effective systems to maintain homogeneity on the evaporator surface at a constant temperature while having high thermal conductivity. Putra et al. [9] investigated the cooling capacity of alcohol, acetone, and distilled water at a heat flux load of $1.61 \mathrm{~W} / \mathrm{cm}^{2}$. They demonstrated that acetone is a potential candidate with a thermal resistance of $0.22 \mathrm{~W} /{ }^{\circ} \mathrm{C}$ and an evaporation temperature of $50{ }^{\circ} \mathrm{C}$. For the hybrid method, Yang et al. [10] studied the thermal performance of a battery thermal management system (BTMS) integrated with mini-channel liquid cooling and air cooling. At $80 \%$ depth of discharge $(D O D)$, the maximum temperature and the temperature difference were decreased by $11.12 \mathrm{~K}$ and $9.52 \mathrm{~K}$, respectively, when the water flow rate increased by $2.2 \times 10^{-4} \mathrm{~kg} / \mathrm{s}$. If the air velocity increased from 0 to $4 \mathrm{~m} / \mathrm{s}$, the battery temperature was reduced by $2.22 \mathrm{~K}$, and the temperature uniformity was decreased by $2.04 \mathrm{~K}$.

Kiani et al. [11] designed a hybrid thermal management system with a nanofluid integrating metal foam and a PCM. Compared with water cooling, the nanofluid with volume fraction of $2 \%$ increased the operating time of the battery by $29 \%$ at a Reynolds number of 420. Jilte et al. [12] investigated heat dissipation in cylindrical batteries with liquid channels and a PCM. At an environment temperature of $40^{\circ} \mathrm{C}$, the surface temperature of the battery was kept under $43^{\circ} \mathrm{C}$ if the PCM was applied, and under $41.2{ }^{\circ} \mathrm{C}$ if the PCM and liquid channels were used simultaneously. Depending on the desired effectiveness, the BTMS can be applied either alone or in combination, but it should meet several criteria: high reliability, easy maintenance, low power consumption, and insignificant mass.

Different numerical modeling approaches have been used to investigate the thermal behavior of Li-ion batteries. They vary from 1D thermal models without thermal interaction among the cells, to complex 3D thermal models which consider non-isothermal and heat generation rates. Jollyn et al. [13] developed a 1D transient battery model based on daily cycles, such as $12 \mathrm{~min}$ and $72 \mathrm{~min}$. They found that a proper PCM thickness was $1.75 \mathrm{~mm}$ when the maximum temperature decrease was $12.9^{\circ} \mathrm{C}$. Greco et al. [14] performed simplified battery thermal management using a PCM/compressed expanded natural graphite (CENG) composite. Their 1D solutions were in good agreement with their 3D results. Hallaj et al. [15] successfully demonstrated that the maximum temperature at the core of a battery pack was $80^{\circ} \mathrm{C}$ with a small temperature variation of $3^{\circ} \mathrm{C}$ at a $10 \mathrm{~A}$ discharge rate. Furthermore, they designed a battery pack integrating a PCM matrix with a significant decrease in charge time and weight for plug-in hybrid vehicles.

In the field of Li-ion battery research, for a 1D model, Hallaj et al. [16] developed a transient-state battery prototype with a thermally homogenous domain. An example is the Sony US18650 battery, which can be scaled up to a Li-ion cell of 100 Ah capacity in safe operating conditions. Sato et al. [17] categorized the heat-generating factors of reaction in a battery as reaction heat, polarization heat, and joule heat. Yi et al. [18] estimated temperature variations over time from electrochemical reactions and ohmic heat. They found that under a constant discharge rate, the potential density on the electrodes is a function of discharge time.

Akeiber et al. [19] predicted the heat storage capacity of a PCM of paraffin (40\% oil and $60 \%$ wax) by solving a 1D numerical model. Fortunato et al. [20] obtained a 2D solution for different temperature profiles and total melting times with a PCM. Samar et al. [21] 
investigated 2D melting procedures for paraffin wax in ANSYS Fluent software, and showed that a PCM container induced a faster melting process.

In the present study, a 1D and a 3D Li-ion battery model were evaluated and compared with experimental data under $3 \mathrm{C}$ and $5 \mathrm{C}$ discharge rates. For a 3D model, two common approaches have been developed: the equivalent circuit model and the Newman, Tiedemann, Gu, and Kim (NTGK) model; the latter was used here. The main objective was to investigate the effect of PCM thickness and thermal conductivity on thermal management performance using the CFD technique with an NTGK model.

\section{Methodology}

A Li-ion battery with a 52.3 Ah pouch cell made by SM Bexel Co., Ltd. (Gumi, Korea) was used here. A $2.3 \mathrm{~mm}$ thick aluminum envelope covered the active zone, and the other fundamental characteristics of the battery are listed in Table 1 .

Table 1. Battery specifications.

\begin{tabular}{ccc}
\hline Parameter & Value & Unit \\
\hline Width $\times$ height $\times$ thickness & $0.249 \times 0.227 \times 0.008$ & $\mathrm{~m}$ \\
Nominal voltage, $V_{n}$ & 3.75 & $\mathrm{~V}$ \\
Nominal capacity, $Q_{n}$ & 52.3 & $\mathrm{Ah}$ \\
Electrical conductivity, $\sigma_{+}$ & $3.77 \times 10^{7}$ & $\mathrm{~S} / \mathrm{m}$ \\
Electrical conductivity, $\sigma_{-}$ & $5.96 \times 10^{7}$ & $\mathrm{~W} / \mathrm{m}$ \\
Thermal conductivity, $k_{b} \cdot \mathrm{K}$ \\
Specific heat, $c_{b}$ & 25.5 & $\mathrm{~J} / \mathrm{kg} \cdot \mathrm{K}$ \\
Density, $\rho_{b}$ & 566 & $\mathrm{~kg} / \mathrm{m}^{3}$ \\
Internal resistance, $R$ & 2695 & $\Omega$ \\
Positive electrode & $6.1 \times 10^{-4}$ & Aluminum-NCM523 \\
Negative electrode & \multicolumn{2}{c}{ Copper-Graphite } \\
Electrolyte & \multicolumn{3}{c}{ Polyethylene } \\
\hline
\end{tabular}

The melting point is the primary criterion when selecting a PCM. It must be both lower than the heat source temperature and higher than the ambient environment to which the system will be subjected [22]. For systems that are designed preferentially for thermal management, the usual advice is to choose a PCM with the highest possible melting point that is considerably below the desired thermal control point $\left(40^{\circ} \mathrm{C}\right)$. Based on our literature review, n-octadecane was suitable for this study with its $T_{\text {solidus }}=301.15 \mathrm{~K}$ (solidus temperature) and $T_{\text {liquidus }}=303.15 \mathrm{~K}$ (liquidus temperature). Its main properties are summarized in Table 2.

Table 2. The material properties of n-octadecane.

\begin{tabular}{cccc}
\hline Parameter & $\begin{array}{c}\text { Solid Phase } \\
T<T_{\text {solidus }}\end{array}$ & $\begin{array}{c}\text { Mushy Zone } \\
T_{\text {solidus }}<T<T_{\text {liquidus }}\end{array}$ & $\begin{array}{c}\text { Liquid Phase } \\
T_{\text {liquidus }}\end{array}$ \\
\hline Density, $\rho\left(\mathrm{kg} / \mathrm{m}^{3}\right)$ & 814 & 769 & 724 \\
Specific heat, $c(\mathrm{~J} / \mathrm{kg} \cdot \mathrm{K})$ & 2150 & 225,000 & 2180 \\
Thermal conductivity, $k(\mathrm{~W} / \mathrm{m} \cdot \mathrm{K})$ & 0.358 & 0.255 & 0.152 \\
Pure solvent melting heat, $L(\mathrm{~J} / \mathrm{kg})$ & & 225,000 & \\
\hline
\end{tabular}

\subsection{One-Dimensional Mathematical Model}

In this study it was assumed that heat transfer only took place through the side surfaces since the battery was thin $(8 \mathrm{~mm})$. In such cases, thermal behavior can be estimated in a cell without considering the thermal interaction among the cells [13]. Bernardi et al. [23] reliably predicted cell temperature and heat generation by a 1D model and proposed a simplified overpotential heat form, taking into account irreversible and reversible heat, as follows:

$$
q_{b}=q_{i r r}+q_{r e v}
$$




$$
\begin{gathered}
q_{i r r}=R I^{2} \\
q_{r e v}=-I T_{b} \frac{\partial E}{\partial T_{b}}
\end{gathered}
$$

Figures 1 and 2 show the experimental measurement of currents over time under different discharge rates.

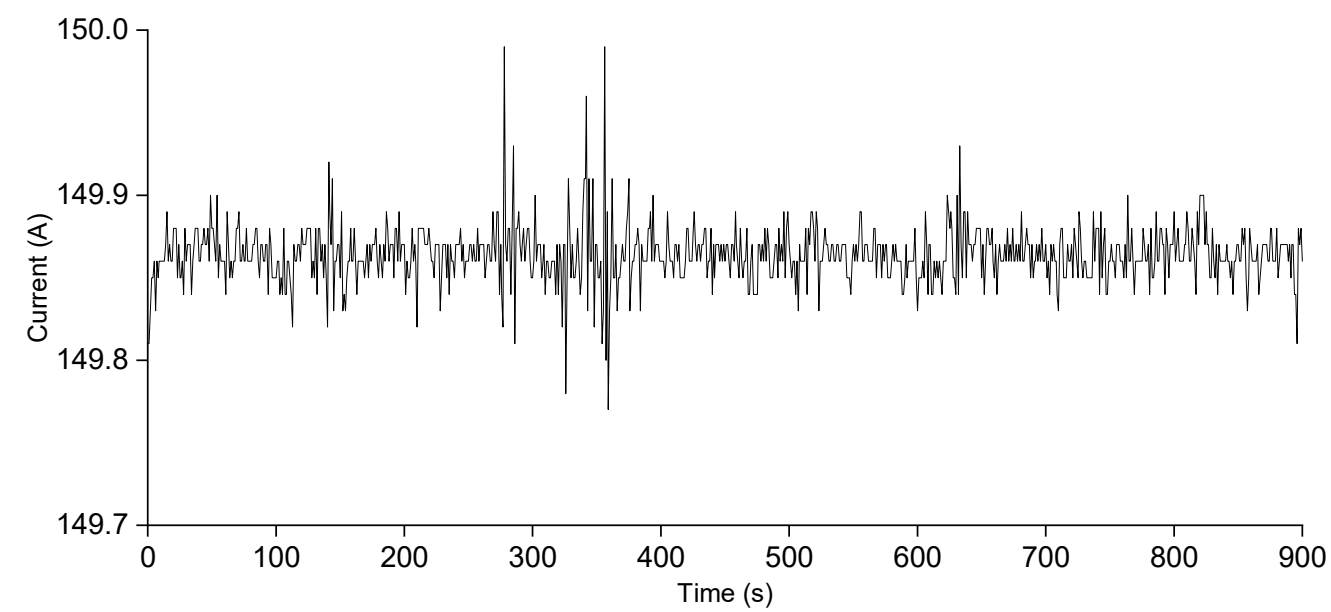

Figure 1. Measured electric current through the battery under $3 \mathrm{C}$ discharge rate.

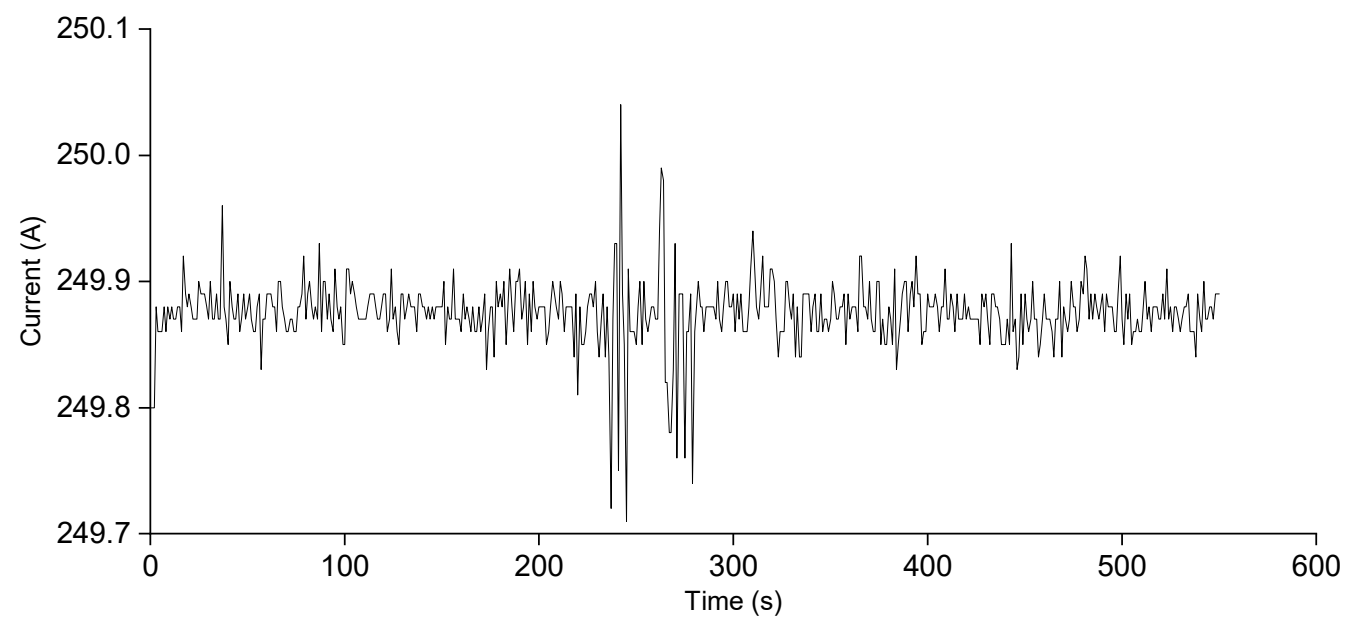

Figure 2. Measured electric current through the battery under $5 \mathrm{C}$ discharge rate.

The $D O D$ is the percentage of the battery capacity that has been discharged from the fully charged battery as presented in Equation (4). An alternative form of $D O D$ is the state of charge (SOC), wherein $0 \%$ refers to a fully discharged battery and $100 \%$ refers to a fully charged battery, as shown in Equation (5) and Figure 3a.

$$
\begin{aligned}
& D O D=\left(Q / Q_{0}\right) \cdot 100 \\
& S O C=100-D O D
\end{aligned}
$$

The open-circuit voltage is determined from the terminal voltage by Equation (6). The entropic heat coefficient, which is estimated in Equation (7), is the derivative of the open-circuit voltage with respect to battery temperature, as shown in Figure $3 \mathrm{~b}$.

$$
E=U+I \cdot R
$$




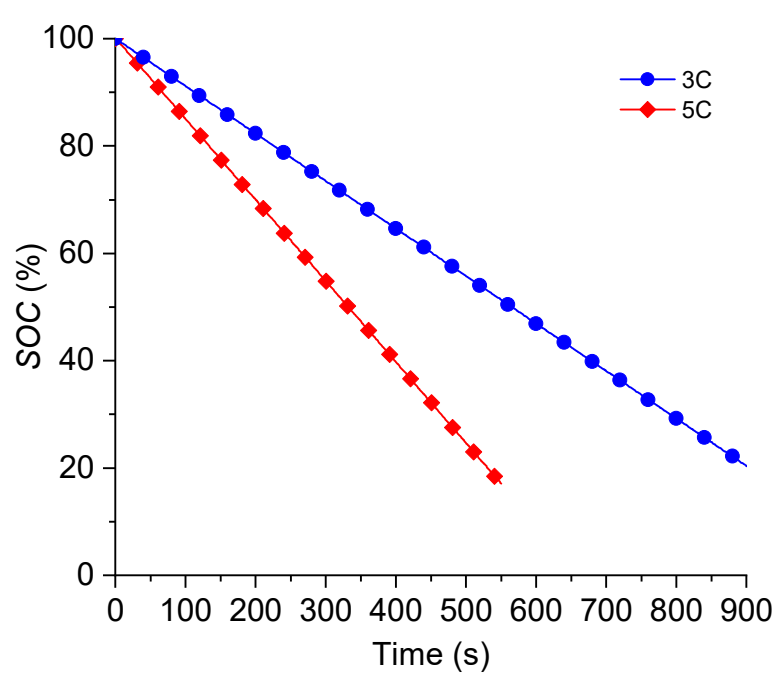

(a)

$$
\frac{\partial E}{\partial T_{b}}=\frac{E^{j+1}-E^{j}}{T_{b}^{j+1}-T_{b}^{j}}
$$

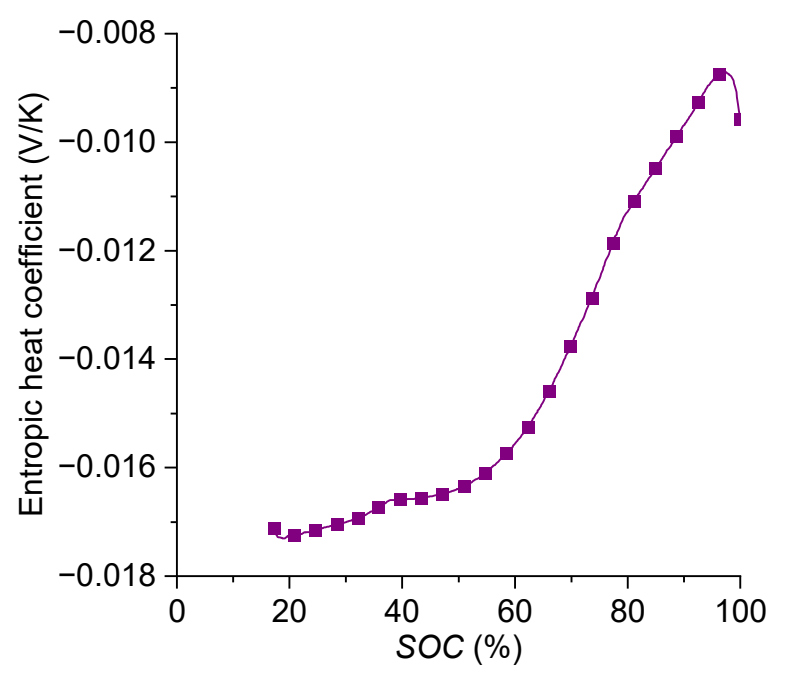

(b)

Figure 3. (a) SOC over time at different discharge rates. (b) Entropic heat coefficient as a function of SOC.

Reversible heat produces an entropy change that can be either negative or positive. Therefore, the entropic heat in Equation (3) is positive if endothermic, negative if exothermic during discharge. The discharge capacity and terminal voltage are also experimentally measured.

The next step is to consider the energy conservation principle. The heat generation rate equals the rate of change in the thermal energy in the cell, plus the rate of heat loss by natural convection, as represented in Equation (8). Thermal resistance for convection $\left(R_{\text {conv }}=3.34 \mathrm{~K} / \mathrm{W}\right)$ on a vertical surface is determined by the Nusselt number, related with the Rayleigh number and the Prandtl number, as shown in Equation (9). The Grasof number is an important standard in determining whether there is laminar flow or turbulent flow in natural convection. In this vertical plate case, the fluid flow was laminar since the Grasof number was equal to $6.11 \times 10^{7}$. The initial battery and environment temperature were set to $25^{\circ} \mathrm{C}$, the same as in the experimental setup.

$$
\begin{gathered}
q_{b}=m_{b} c_{b} \frac{d T_{b}}{d t}+\frac{2\left(T_{b}-T_{a}\right)}{R_{\text {conv }}} \\
\mathrm{Nu}=0.68+\frac{0.67 \mathrm{Ra}^{1 / 4}}{\left[1+(0.492 / \mathrm{Pr})^{9 / 16}\right]^{4 / 9}}
\end{gathered}
$$

The PCM was stored in an aluminum container, one surface of which was in contact with the battery and the other was cooled by natural convection. The dominant heat transfer mechanism was conduction in the PCM due to the thin PCM layers. Thermal energy was conducted from a battery source throughout the aluminum case and the PCM to the air at room temperature, as shown in Figure 4. In accordance with the instantaneous energy balance, heat produced by the battery could either be stored by itself or flowed into the PCM region, as follows:

$$
q_{b}=m_{b} c_{b} \frac{d T_{b}}{d t}+q_{P C M}
$$




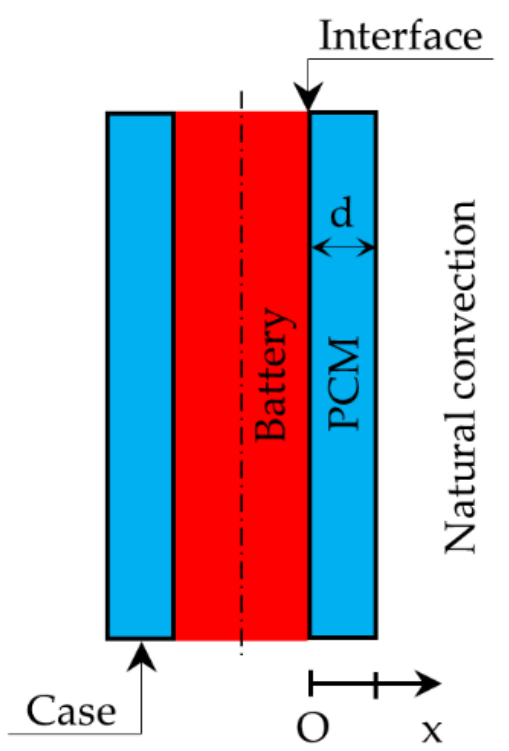

Figure 4. Schematic of the battery and PCM positions.

A 1D transient heat conduction equation, without heat generation, was applied to evaluate the temperature distribution in the PCM, as shown in Equation (11) [24]:

$$
\begin{aligned}
\frac{\partial T}{\partial t} & =\alpha \frac{\partial^{2} T}{\partial^{2} x} \\
\alpha & =\frac{k}{\rho \cdot c}
\end{aligned}
$$

Boundary conditions were applied as follows:

$$
\begin{array}{lrl}
\text { At } x=0 & k A \frac{\partial T}{\partial x}=\frac{T_{b}-T(x)}{R_{\text {int }}+R_{\text {cas }}}=\frac{q_{P C M}}{2} \\
\text { At } x=d & k A \frac{\partial T}{\partial x}=\frac{T(x)-T_{a}}{R_{\text {cas }}+R_{\text {conv }}}
\end{array}
$$

It is truly necessary to clarify two forms of heat when using a PCM. Sensible heat results in a change in material temperature without a phase change. By contrast, latent heat does not increase the temperature within the material but does cause a change of substance state [22]. Assuming that the roughness of the aluminum plates was $10 \mu \mathrm{m}$, thermal contact conductance was calculated to be $3640 \mathrm{~W} / \mathrm{m}^{2} \cdot \mathrm{K}$. Jollyn et al. [13] used a case thickness of $5 \mathrm{~mm}$; accordingly, the thermal resistance for conduction was equal to $3.732 \times 10^{-5} \mathrm{~K} / \mathrm{W}$.

\subsection{Three-Dimensional Mathematical Model}

Numerical simulation of the heat transfer was carried out using ANSYS Fluent software. Kim et al. [25] introduced the multi-scale, multi-dimensional approach for solving interactions appearing in a vast number of length scales. This framework efficiently deals with separate solution domains at the particle $\left(10^{-9}\right.$ to $\left.10^{-8}\right)$, electrode $\left(10^{-6}\right.$ to $\left.10^{-4}\right)$, and cell $\left(10^{-2}\right.$ to $\left.10^{0}\right)$ levels. At the cell scale, the current flux is governed by the following equations:

$$
\begin{gathered}
\nabla \cdot\left(\sigma_{+} \nabla \varphi_{+}\right)=-j \\
\nabla \cdot\left(\sigma_{-} \nabla \varphi_{-}\right)=j
\end{gathered}
$$

The NTGK model assumes the current flux to be a function of the potential difference between the positive and negative electrodes. Ho et al. [26] estimated two empirical fitting parameters from their experimental data. Those depend on the DOD of the battery and 
the temperature. For a 3D thermal model of Li-ion batteries, the thermal source is roughly similar to 1D modeling and the ohmic heating is also considered in the batteries, as follows:

$$
q_{b}=j\left[E-\left(\varphi_{+}-\varphi_{-}\right)-T \frac{d E}{d T_{b}}\right]+\sigma_{+} \cdot \nabla^{2} \varphi_{+}+\sigma_{-} \cdot \nabla^{2} \varphi_{-}
$$

where $j\left[E-\left(\varphi_{+}-\varphi_{-}\right)\right]$is expressed as an irreversible source term and $j T\left(d E / d T_{b}\right)$ refers to a reversible source term. The thermal energy generated in the current collecting tab and lead wire was neglected.

Voller et al. [27] successfully solved phase change problems in the convection-diffusioncontrolled mushy zone with the enthalpy-porosity technique, which relies on fixed-grid methodology. Depending upon the PCM temperature, the liquid fraction is defined as:

$$
\begin{array}{ll}
\beta=0 & \text { for } T<T_{\text {solidus }} \\
\beta=1 & \text { for } T>T_{\text {liquidus }} \\
\beta=\frac{T-T_{\text {solidus }}}{T_{\text {liquidus }}-T_{\text {solidus }}} & \text { for } T_{\text {solidus }}<T<T_{\text {liquidus }}
\end{array}
$$

Instead of tracking the melting interface, the liquid fraction referring to the liquid state in a computational domain is computed per iteration. The latent heat content is as follows:

$$
\Delta H=\beta \cdot L
$$

For melting simulations, the momentum equation is not employed. The energy equation analyzing the temperature distribution can be derived as follows:

$$
\frac{\partial}{\partial t}(\rho H)+\nabla \cdot(\rho \mathbf{v} H)=\nabla \cdot(k \nabla T)+S
$$

where $\mathbf{v}$ is the fluid velocity vector.

\subsection{Validation}

\subsubsection{Validation of 1D Modeling}

The 1D battery heat transfer model was validated against the experimental data. The error between the 1D model prediction and the experimental data was found to be within $1 \%$ at the last stage of both the $3 \mathrm{C}$ and $5 \mathrm{C}$ discharge processes. Figure 5 shows good quantitative agreement for the $3 \mathrm{C}$ and $5 \mathrm{C}$ discharge rates.

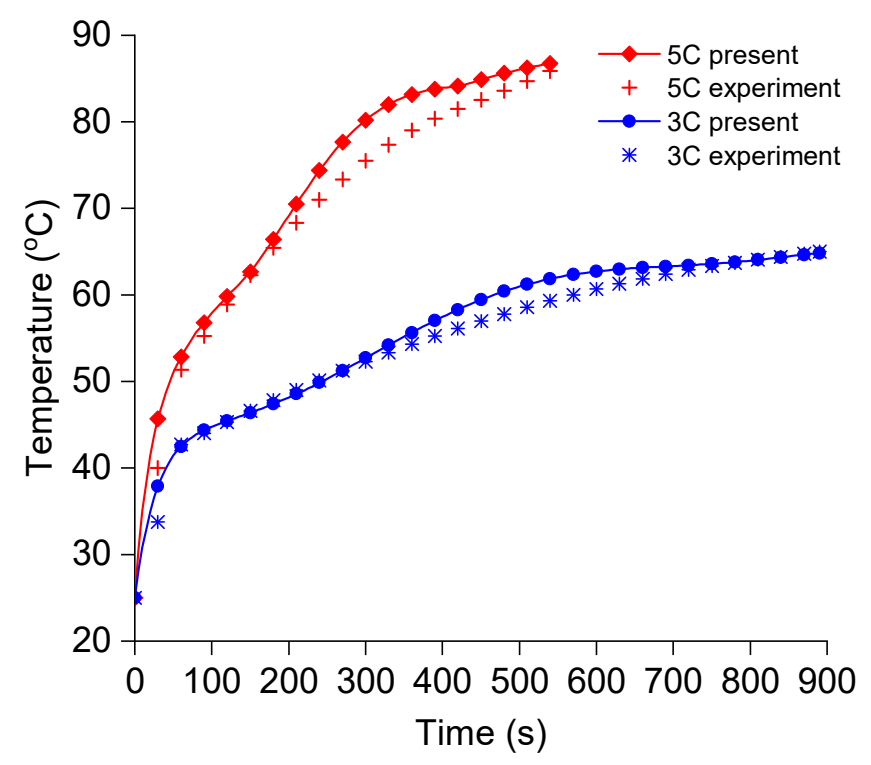

Figure 5. Comparison of the 1D model and the experimental maximum temperatures in the battery. 


\subsubsection{Validation of 3D Modeling}

Ho et al. [26] conducted simulations on the same kind of Li-ion battery using ANSYS Fluent software. The NTGK model was used to predict the thermal behavior of the battery under various discharge rates: $1 \mathrm{C}, 2 \mathrm{C}, 3 \mathrm{C}, 4 \mathrm{C}$, and $5 \mathrm{C}$. A cell was immersed in air that had an initial temperature of $25^{\circ} \mathrm{C}$. As seen in Figure 6, there were similar trend lines between this current work and that of Ho et al. At the end of discharging, there was a $0.1 \%$ error for the $3 \mathrm{C}$ rate and a $0.5 \%$ error for the $5 \mathrm{C}$ rate. This confirmed that NTGK battery modeling was valid for various rates of discharge.

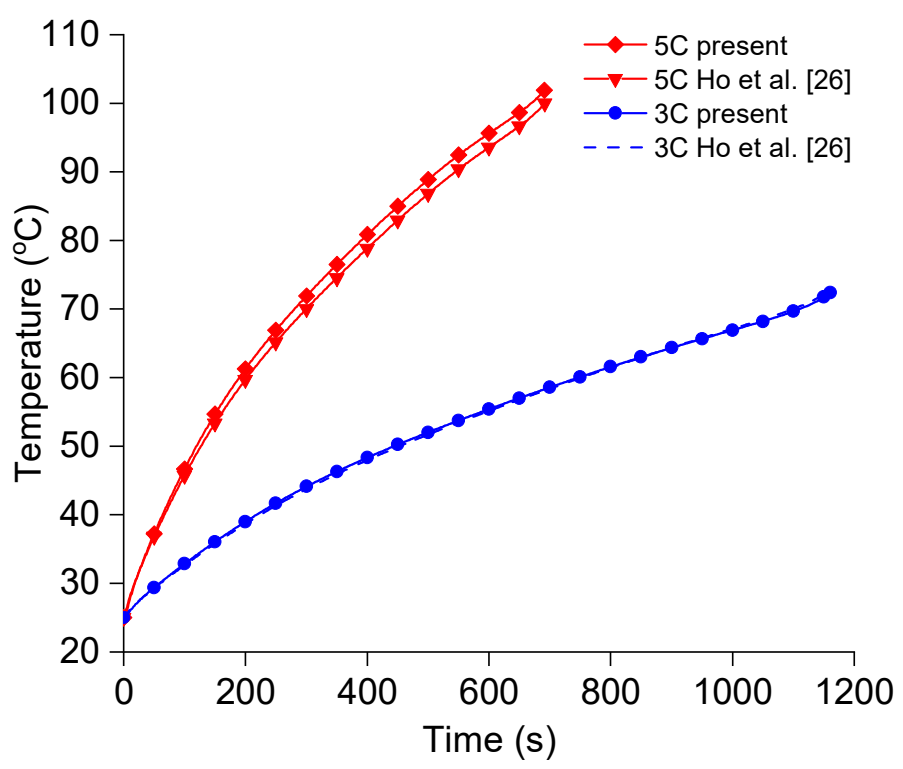

Figure 6. Comparison of temperatures by the NTGK model in this study and by Ho et al. [26].

A transient simulation of the thermal behavior of a Li-ion battery with a PCM was validated to the results of Javani et al. [28]. The error was found to be within an acceptable range (a maximum error of less than $1 \%$ at the end of discharging), as shown in Table 3. In order to model a cell, those researchers assumed a uniform heat generation rate within the cell domain. Due to the inconsequential thickness of the battery, this assumption was appropriate for the lumped system evaluation. We considered a transient model of a $54,374.5 \mathrm{~W} / \mathrm{m}^{3}$ heat source, especially because there was anisotropic thermal conductivity in the cell: $25 \mathrm{~W} / \mathrm{m} \cdot \mathrm{K}$ along the cell surface and $1 \mathrm{~W} / \mathrm{m} \cdot \mathrm{K}$ normal to the cell surface. $\mathrm{N}$-octadecane, the length of which was $3 \mathrm{~mm}$, was integrated around the periphery of the battery with the same thickness. It was assumed that free convection took place at all the surfaces where the battery and the PCM interfaced with the ambient air. The heat transfer coefficient was $7 \mathrm{~W} / \mathrm{m}^{2} \cdot \mathrm{K}$ and the temperature of the environment was $294.15 \mathrm{~K}$. The geometrical features of this model, which had 300,800 elements, are summarized in Table 4.

Table 3. Comparison of maximum temperature for the validation of the battery model at $20 \mathrm{~min}$.

\begin{tabular}{cccc}
\hline Configuration & Present Study & Javani et al. [28] & Error (\%) \\
\hline Cell minimum temperature (K) & 303.20 & 305.05 & 0.6 \\
Cell average temperature (K) & 305.23 & 307.58 & 0.8 \\
Cell maximum temperature (K) & 306.25 & 308.43 & 0.7 \\
\hline
\end{tabular}

A thorough grid independence test should be carried out to demonstrate that the element size does not affect the quantity of interest. We recorded the temperature in the cell at the end of discharging at the $5 \mathrm{C}$ discharge rate. As shown in Figure 7, the 
grid with 1,360,891 elements was sufficient to predict the temperature distribution in the computational domain.

Table 4. Dimensions of the battery and PCM geometry in the simulations of Javani et al. [28].

\begin{tabular}{cccc}
\hline Geometry & Length $(\mathbf{m})$ & Height $(\mathbf{m})$ & Thickness $(\mathbf{m})$ \\
\hline Cell & 0.146 & 0.194 & 0.0054 \\
Terminal & 0.035 & 0.015 & 0.0006 \\
PCM & 0.003 & 0.003 & 0.0054 \\
\hline
\end{tabular}

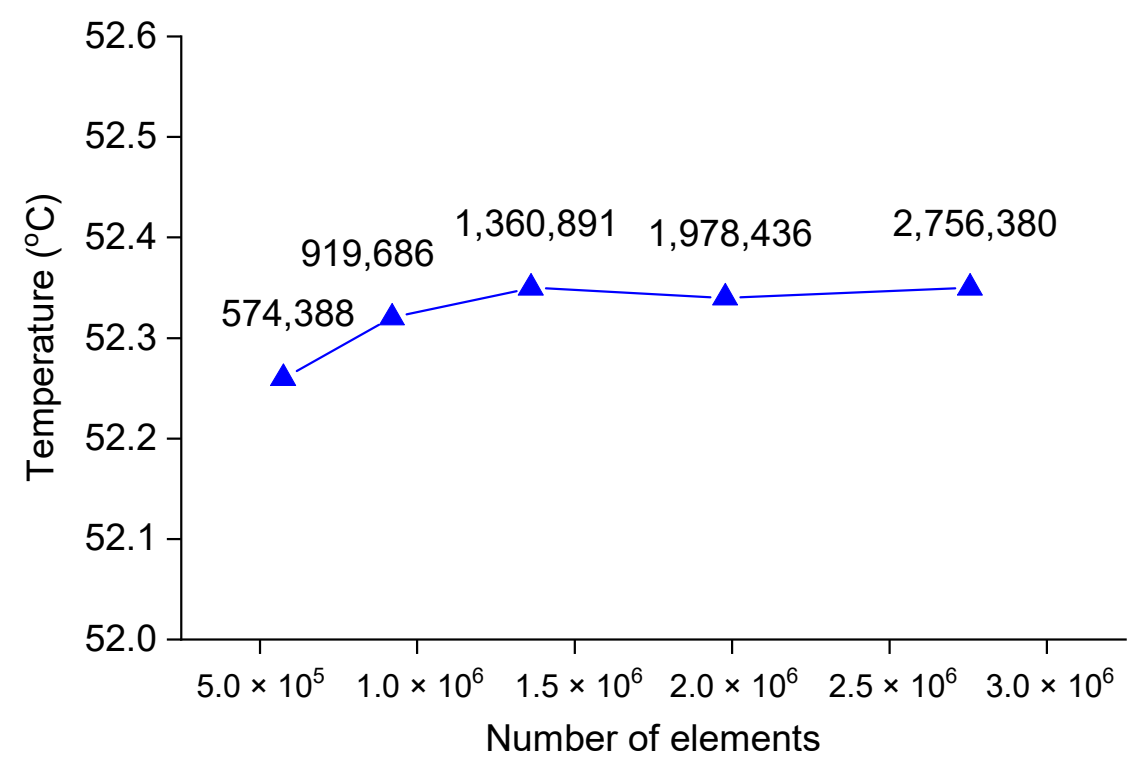

Figure 7. Grid independence test with different numbers of elements.

\section{Results and Discussion}

In this study, the effect of the thickness and thermal conductivity of a PCM on the cooling performance of a Li-ion battery are investigated. The PCM was of three different thicknesses, $0.5 \mathrm{~mm}, 0.55 \mathrm{~mm}$, and $0.6 \mathrm{~mm}$, and the thermal conductivity of the PCM was enhanced based on the practical application.

\subsection{Effect of PCM Thickness}

The major drawback with most organics, particularly the family of paraffins, is that they possess low thermal conductivity. A thin PCM easily melts fully and does not produce sufficiently effective temperature reduction. With a thick PCM there is a solid region farther from the battery and a superheated liquid region next to the battery, so instead of behaving as a thermal sink, the PCM may behave as a thermal isolator.

As shown in Figure 8, the maximum temperatures of the Li-ion batteries without a PCM were $64.86^{\circ} \mathrm{C}$ and $86.83^{\circ} \mathrm{C}$ at the end of the $3 \mathrm{C}$ and $5 \mathrm{C}$ discharge rates, respectively. As mentioned previously, the best temperature range is $25^{\circ} \mathrm{C}$ to $40{ }^{\circ} \mathrm{C}$ and the safe temperature range is $-20^{\circ} \mathrm{C}$ to $60^{\circ} \mathrm{C}$ for Li-ion battery operation. Moreover, the capacity fade of Li-ion cells can be $36.21 \%$ after 800 cycles when the operating temperature is around $45^{\circ} \mathrm{C}$, and the loss can even reach $70.56 \%$ after 500 cycles when the operating temperature is approximately $55^{\circ} \mathrm{C}$. At the $3 \mathrm{C}$ discharge rate, a PCM with a thickness of $0.6 \mathrm{~mm}$ or thinner can maintain the battery temperature in a safe condition. With a $0.6 \mathrm{~mm}$ thick PCM layer, the maximum temperature can decrease by $1.28^{\circ} \mathrm{C}$ or $6.54{ }^{\circ} \mathrm{C}$, depending on the fast or slow discharge rate. 


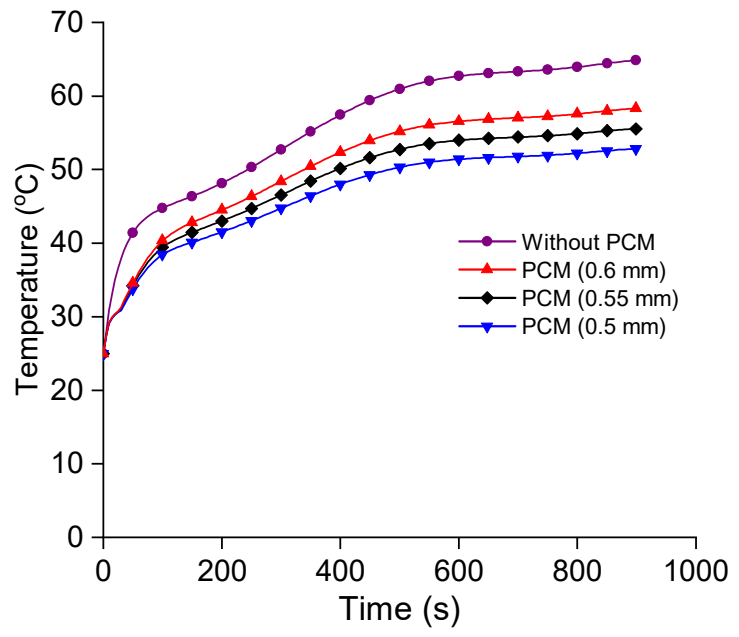

(a)

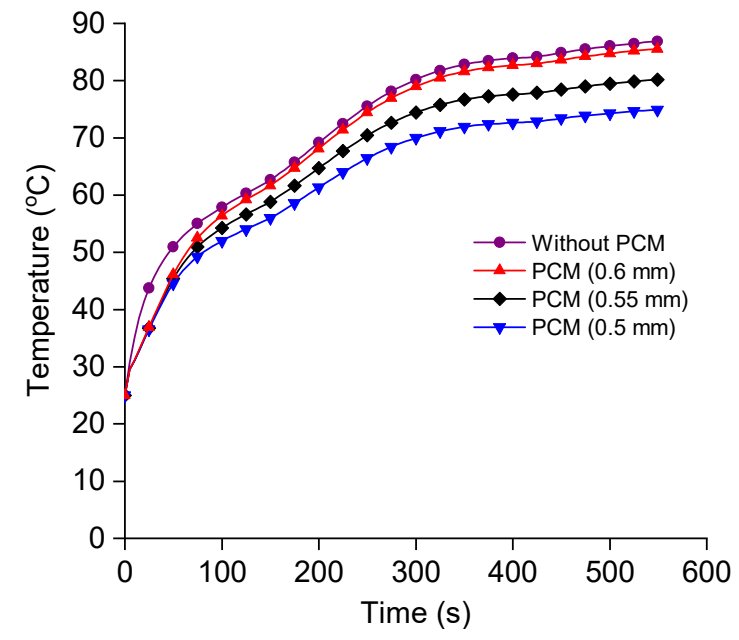

(b)

Figure 8. Battery temperatures for different PCM thicknesses at: (a) 3C discharge rate; (b) 5C discharge rate.

Three stages along the temperature elevation curve clearly exist in the battery with a PCM (Figure 8).

- $\quad$ From a starting temperature of less than $28^{\circ} \mathrm{C}$, it grows markedly. It takes about the first $3 \mathrm{~s} \mathrm{(5s)}$ to reach the limitation for the 5C (3C) discharge rate. The slope was similar to the one without PCM. The energy storage relies solely on low sensible heating (in this case, $2150 \mathrm{~J} / \mathrm{kg} \cdot \mathrm{K})$.

- During the melting process, the battery temperature drops into the phase change temperature range. The temperature increases slightly since thermal energy is absorbed as the heat of transformation. Under the $3 \mathrm{C}$ discharge rate, this process occurred in $20 \mathrm{~s}$ to increase the temperature to $\sim 31^{\circ} \mathrm{C}$. The PCM started to melt from the inner to the outer layer, and then melted entirely.

- Finally, the PCM was at a liquid state with both low thermal conductivity and low specific heat. The temperature of the battery climbed considerably again but the slope was still less than the one without a PCM. The predicted temperatures had almost identical trends in their final stages.

Figure 9 is a close-up of the battery temperature change at the initial stage of the discharging process. Under the high discharge rate of $5 \mathrm{C}$, it took $17.4 \mathrm{~s}$ to rise above $40{ }^{\circ} \mathrm{C}$. This process could be extended to $34.8 \mathrm{~s}$ when the PCM thickness was $0.5 \mathrm{~mm}$. Similarly, with the $3 \mathrm{C}$ discharge rate, it took much longer $(40.3 \mathrm{~s})$ to reach $40{ }^{\circ} \mathrm{C}$. This operation could take up to $144.3 \mathrm{~s}$ with a $0.5 \mathrm{~mm}$ thick PCM.

As shown in Figure 10, at the end of the discharging process the battery temperature linearly varied with the thickness of the PCM. When the thickness decreased by $0.05 \mathrm{~mm}$, the temperature also declined $5.3^{\circ} \mathrm{C}$ at the $5 \mathrm{C}$ discharge rate. This compares with a decline of $2.7^{\circ} \mathrm{C}$ at the low discharge rate of $3 \mathrm{C}$.

\subsection{Effect of PCM Thermal Conductivity}

The response time is a substantial factor in the design of a PCM system. There are several approaches to improve heat dissipation, such as enhancing the thermal conductivity, setting the ullage space far from the heat source via a potential container, and installing the PCM in the heat flow path. It is generally agreed that a material that has a high energy storage capacity will have low thermal conductivity. Therefore, much research interest has been focused on enhancing the thermal conductivity of PCMs. 


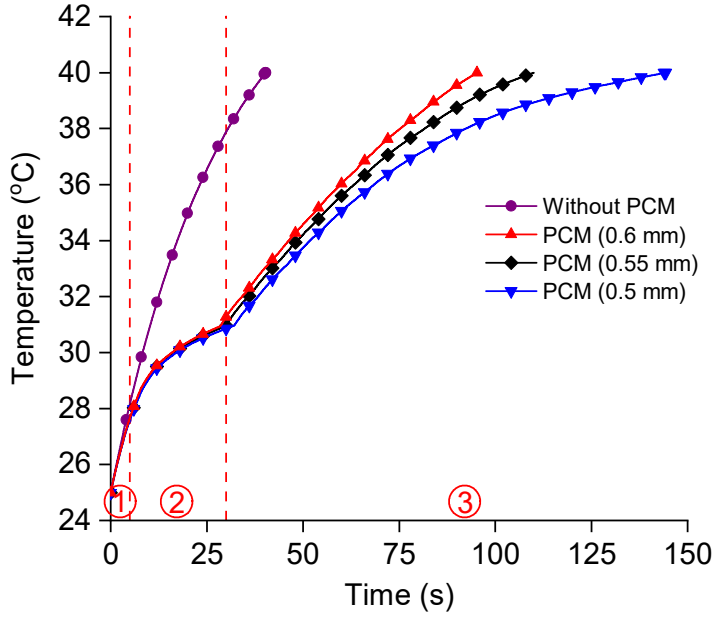

(a)

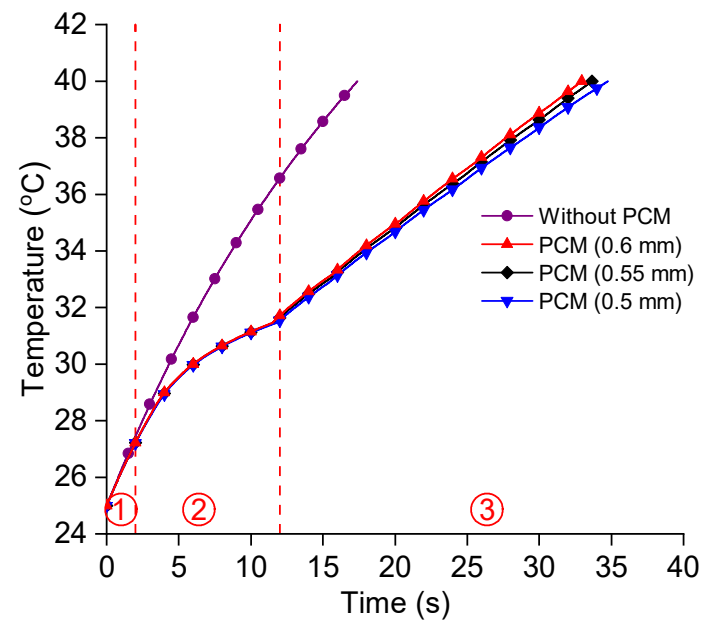

(b)

Figure 9. Rapid increases in the temperature below $40^{\circ} \mathrm{C}$ at: (a) the $3 \mathrm{C}$ discharge rate; (b) the $5 \mathrm{C}$ discharge rate (1: sensible heating of solid; 2: latent heat of fusion; 3 : sensible heating of liquid).

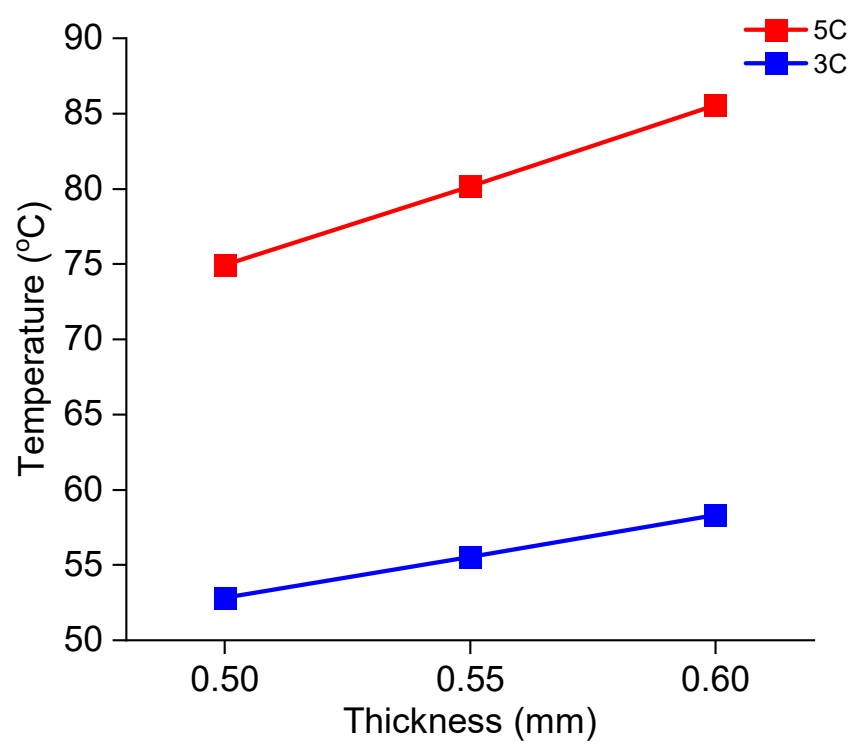

Figure 10. The highest battery temperature as a function of PCM thickness.

Recently, Venkateshwar et al. [29] investigated heat storage performance when embedding aluminum metal foam (MF) in n-octadecane. They used Equations (21) and (22) to determine the effective thermal conductivity of that PCM-MF composite, given as:

$$
\begin{aligned}
& k_{s, e f f}=A_{1}\left[\varepsilon \cdot k_{s, P C M}+(1-\varepsilon) k_{M F}\right]+\frac{1-A_{1}}{\frac{\varepsilon}{k_{s, P C M}}+\frac{1-\varepsilon}{k_{M F}}} \\
& k_{l, e f f}=A_{1}\left[\varepsilon \cdot k_{l, P C M}+(1-\varepsilon) k_{M F}\right]+\frac{1-A_{1}}{\frac{\varepsilon}{k_{l, P C M}}+\frac{1-\varepsilon}{k_{M F}}}
\end{aligned}
$$

With the porosity $\varepsilon$ set to 0.972 , the structure with a thermal conductivity of $2.394 \mathrm{~W} / \mathrm{m} \cdot \mathrm{K}$ conducted faster than pure n-octadecane without sacrificing the available volume.

Sari et al. [30] examined the transient thermal influence of paraffin absorbed into expanded graphite (EG). They determined that the PCM composite, with a $10 \%$ mass fraction of EG, had stable properties. The thermal conductivity of the PCM-EG linearly 
varied with the mass fraction of the EG. Compared with pure n-octadecane, the thermal conductivity could reach $0.828 \mathrm{~W} / \mathrm{m} \cdot \mathrm{K}$ when integrated with the proper amount of EG.

In a macroscopic approach, the use of carbon fibers (CF) was considered by Fukai et al. [31] as an advanced technique. The effective thermal conductivity of the PCM composite was around three times higher than the pure PCM at $X_{f a}=0.012$, as calculated in the following formula:

$$
k_{e f f}=\left[\left(3.31 \times 10^{-3}+1.69 X_{f a}-2.65 \times 10 \times X_{f a}^{2}\right) \cdot\left(\frac{k_{f}}{k_{m}}-1\right)^{0.67}+1\right] k_{m}
$$

As a result, the thermal conductivity of paraffin combined with $\mathrm{CF}$ was $0.678 \mathrm{~W} / \mathrm{m} \cdot \mathrm{K}$.

Figure 11 shows the battery temperature change during the discharging process under natural convection. The higher the thermal conductivity of the PCM composite is, the more effective the heat dissipation capacity is. Additionally, aluminum foams make the melting process more uniform. The thermal improvements of PCM composites are summarized in Table 5. At the end of the discharging process, the percentage of temperature reduction with PCM-MF was about 1.2 and 1.3 times higher than with PCMEG and PCM-CF, respectively.

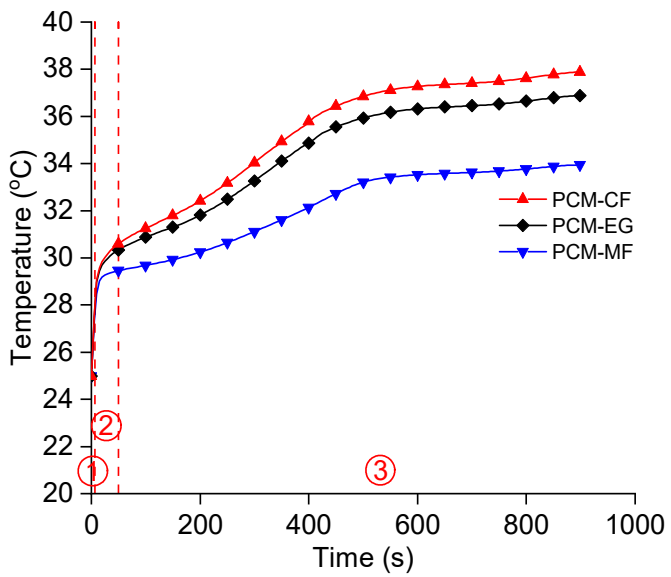

(a)

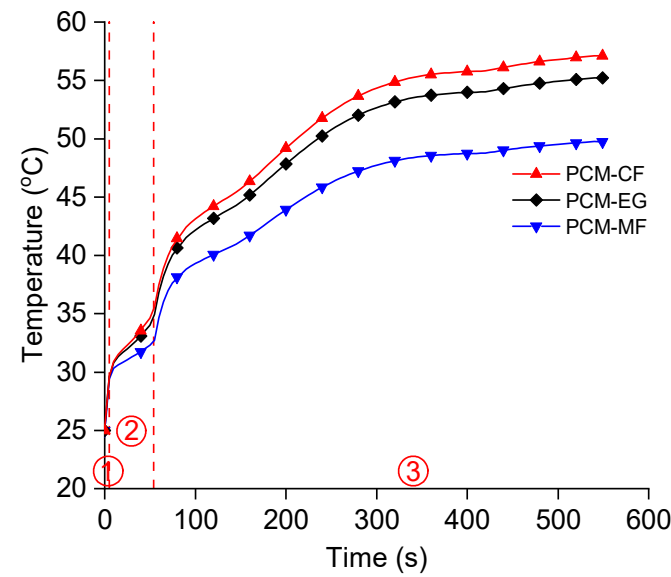

(b)

Figure 11. Battery temperature with various PCM composites at: (a) the $3 \mathrm{C}$ discharge rate; (b) the $5 \mathrm{C}$ discharge rate (1: sensible heating of solid; 2 : latent heat of fusion; 3: sensible heating of liquid).

Table 5. Specifications of PCM composites and their performances.

\begin{tabular}{ccccccc}
\hline & Parameter & Pure PCM & PCM-MF & \multicolumn{2}{c}{ PCM-EG } & PCM-CF \\
\hline \multirow{2}{*}{$3 \mathrm{C}$} & Thermal conductivity $(\mathrm{W} / \mathrm{m} \cdot \mathrm{K})$ & 0.255 & 2.394 & & 0.828 & 0.678 \\
\hline \multirow{2}{*}{$5 \mathrm{C}$} & Maximum temperature $\left({ }^{\circ} \mathrm{C}\right)$ & 52.8 & 33.9 & 36.9 & 37.9 \\
& Percent reduction $(\%)$ & 0 & 35.8 & 30.1 & 28.2 & 57.1 \\
& Maximum temperature $\left({ }^{\circ} \mathrm{C}\right)$ & 74.9 & 49.7 & 55.2 & 26.3 & 23.8 \\
\hline
\end{tabular}

\subsection{Comparison of $1 D$ Calculation and $3 D$ Simulation}

We compared our 1D analysis and a 3D simulation of the $0.5 \mathrm{~mm}$ thick PCM-MF model. A hexahedral grid was generated for the battery and the PCM domain, while the ambient air domain was divided by polyhedral elements, as shown in Figure 12. The bottom was set to be adiabatic and the other surfaces were set to atmospheric pressure. For the pressure-velocity coupling, the ANSYS Fluent coupled algorithm was employed. A second-order interpolation scheme was used to approximate the convection terms in 
the momentum, energy, and potential equations, whereas a PREssure STaggering Option (PRESTO) scheme was selected for the pressure field. For the conjugate heat transfer problem, the following assumptions were applied:

- Only natural laminar convection took place in the ambient environment.

- The initial temperature of the battery and the PCM were set to the same as the ambient temperature $\left(25^{\circ} \mathrm{C}\right)$.

- There was no flow in the PCM liquid phase.

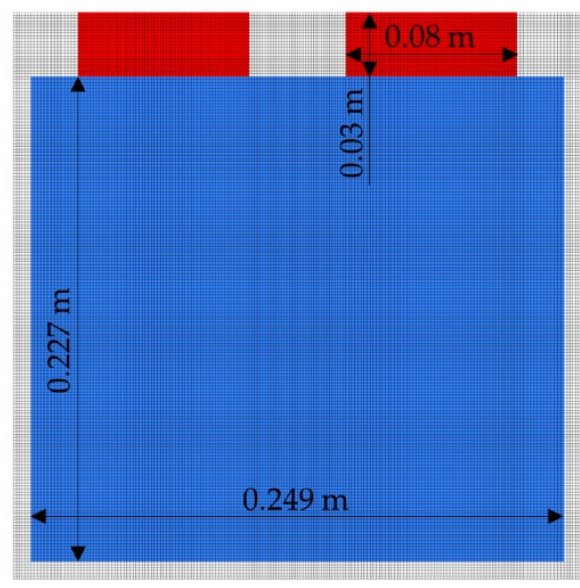

(a)

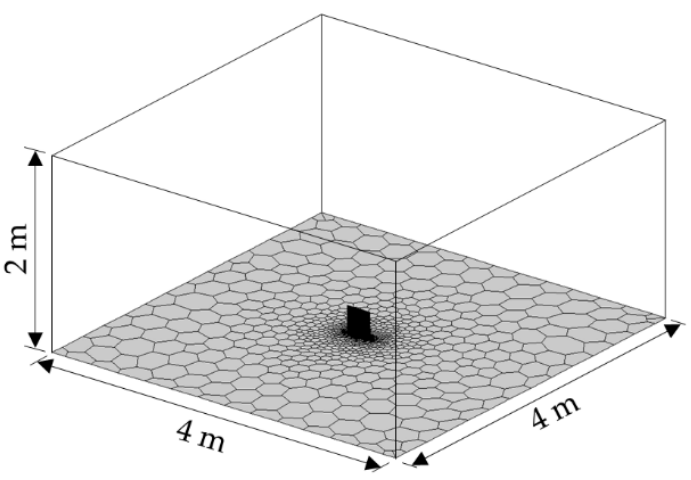

(b)

Figure 12. (a) Battery and PCM immersed in air. (b) The computational domain.

The data from the late stage of the analysis for the 1D calculation was excluded because it was too noisy; nevertheless, we found that the 1D and 3D solutions matched well when extending the results while maintaining the curve slope (Figure 13). This agreed with the results of Greco et al. [14], who showed that cooling paths were totally dissimilar in the initial periods of the analytical and computational approaches, but they definitely matched at the end stages.

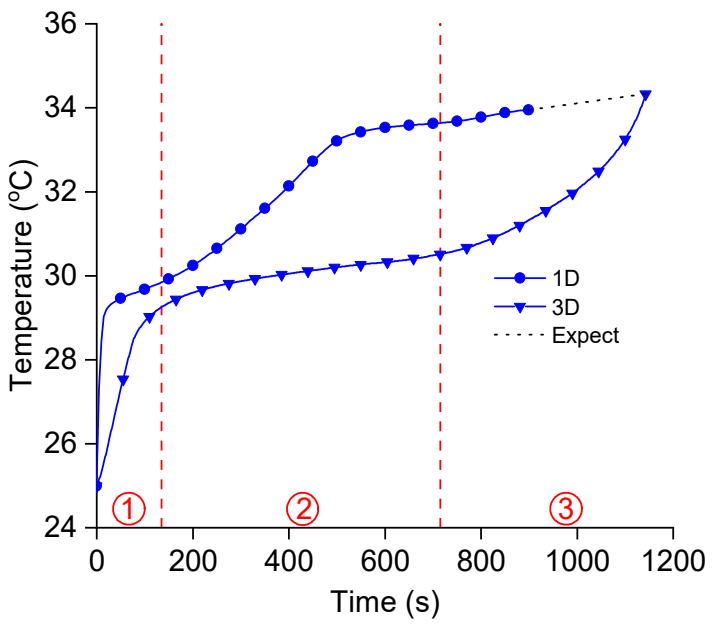

(a)

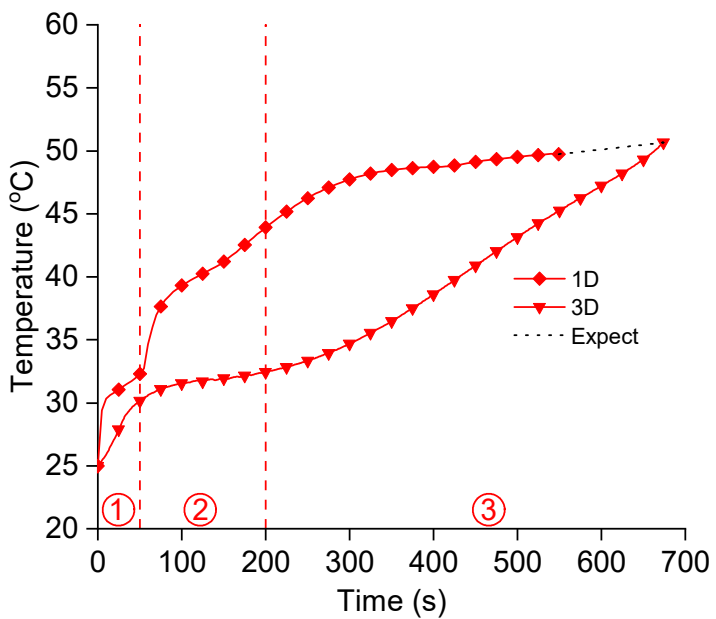

(b)

Figure 13. Comparison of $1 \mathrm{D}$ and $3 \mathrm{D}$ simulation results for battery temperatures under: (a) the $3 \mathrm{C}$ discharge rate; (b) the 5C discharge rate (1: sensible heating of solid; 2: latent heat of fusion; 3: sensible heating of liquid).

Figure 14 shows the temperature uniformity in the 3D Li-ion battery model. At the low discharge rate of $3 \mathrm{C}$, the tmperature disparity in the cell was maintained under $5{ }^{\circ} \mathrm{C}$. At the higher discharge rate of $5 \mathrm{C}$, it markedly escalated due to sudden heat generation. 
However, the PCM exhibited outstanding improvement, with a $6.6^{\circ} \mathrm{C}$ peak difference of temperature.

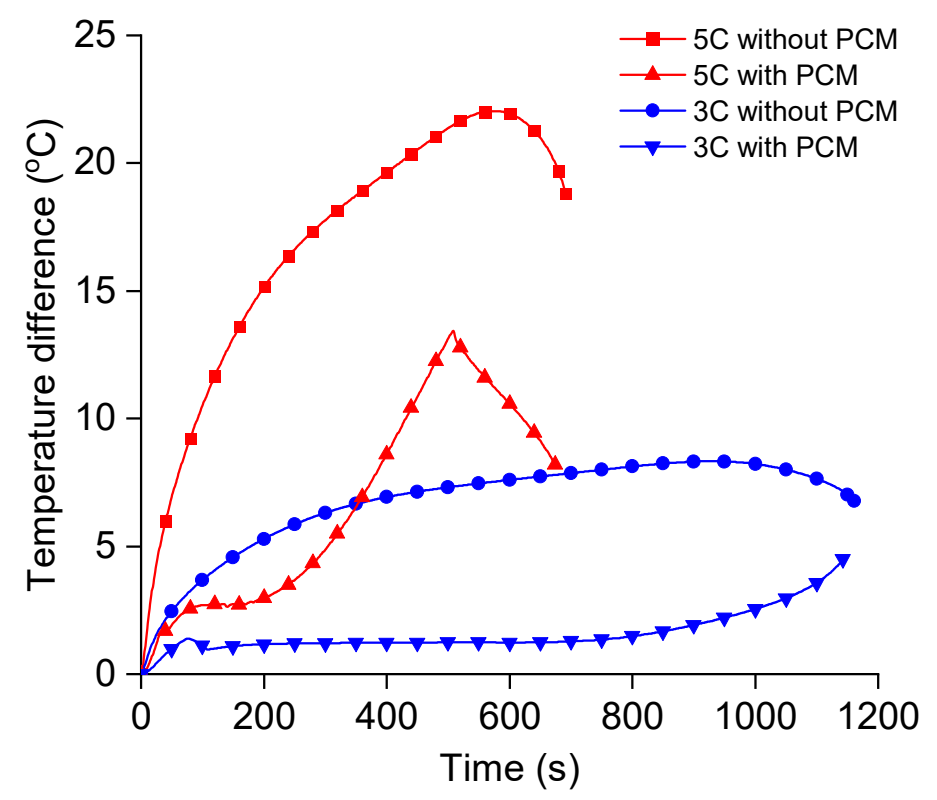

Figure 14. Investigation of temperature uniformity in the 3D Li-ion battery model.

At the center plane of the cell, two monitoring lines were selected to explore the temperature change at $\mathrm{z}=0.1245 \mathrm{~m}$ and $\mathrm{y}=0.1135 \mathrm{~m}$, as depicted in Figure 15a. Figure $15 \mathrm{~b}$ shows the temperature along the vertical line at the end of discharging. There was a large difference of $15.5^{\circ} \mathrm{C}$ between the top and bottom positions under the $5 \mathrm{C}$ rate without a PCM. The use of PCM-MF caused a sudden change in temperature in the lower area of the cell at the 3 C discharge rate, due to a liquid mushy PCM zone. It can be seen in Figure 15c that the temperature varied slightly in the horizontal direction and tended to be more stable when the PCM was applied. All of the differences were below $1^{\circ} \mathrm{C}$. Because the heat source was concentrated in the region close to the current collecting tabs, the temperature variation was clearly greater in the vertical direction than in the horizontal direction.

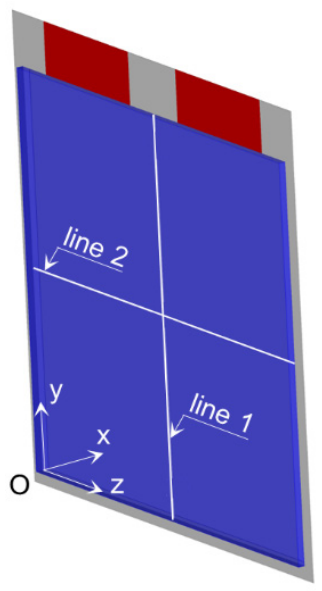

(a)

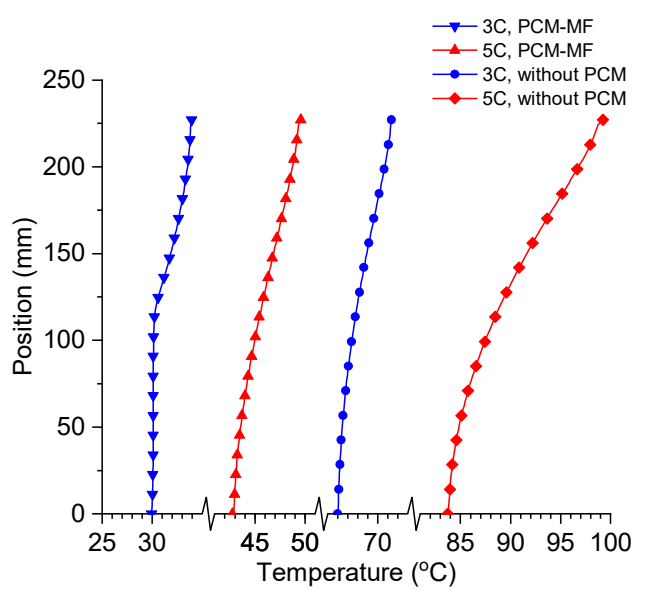

(b)

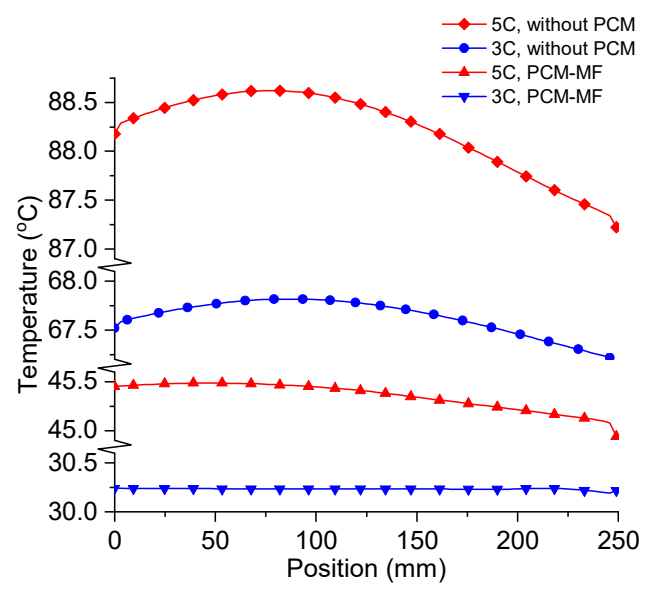

(c)

Figure 15. (a) Temperature monitoring lines. (b) The temperature distribution at line 1. (c) The temperature distribution at line 2.

Basically, the temperature distribution on the battery surface can be divided into two parts: an upper region with higher temperature and a lower region with lower temperature. 
Without a PCM, the battery temperature increased more continuously and homogeneously from the bottom to the top under the $3 \mathrm{C}$ discharge rate. This difference was $6.8^{\circ} \mathrm{C}$. However, there was greater difference in temperature $\left(18.8^{\circ} \mathrm{C}\right)$ under the $5 \mathrm{C}$ discharge rate. The highest temperature was located near the positive and negative tabs, as shown in Figure 16.

$3 \mathrm{C}$
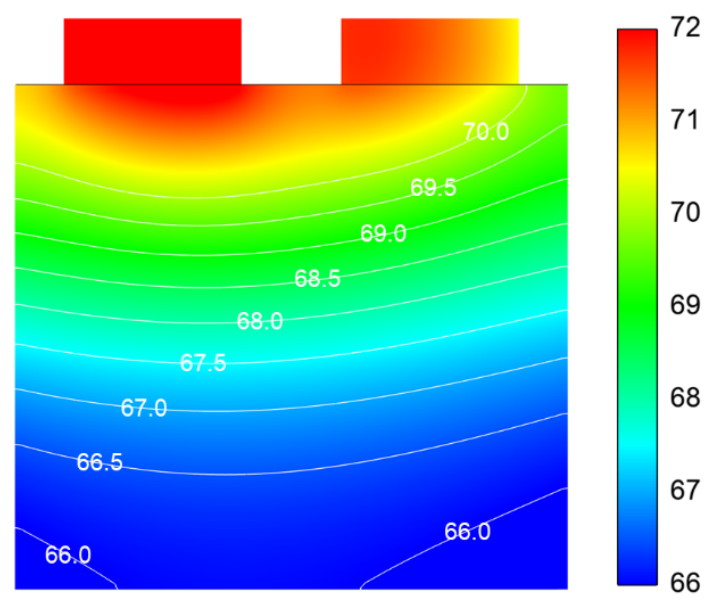

5C

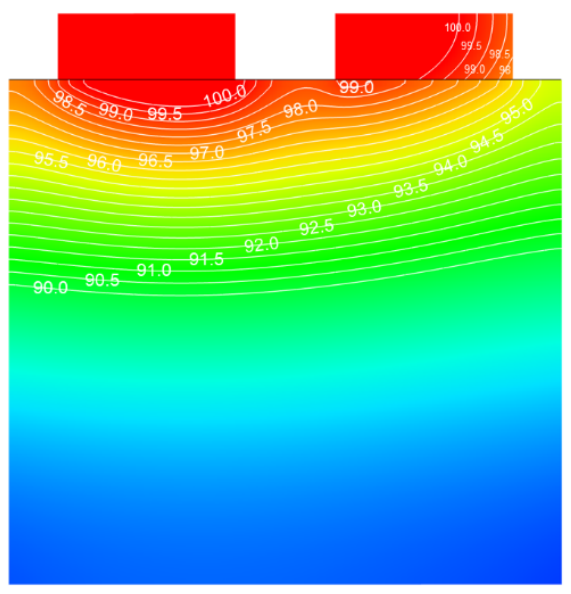

(a)
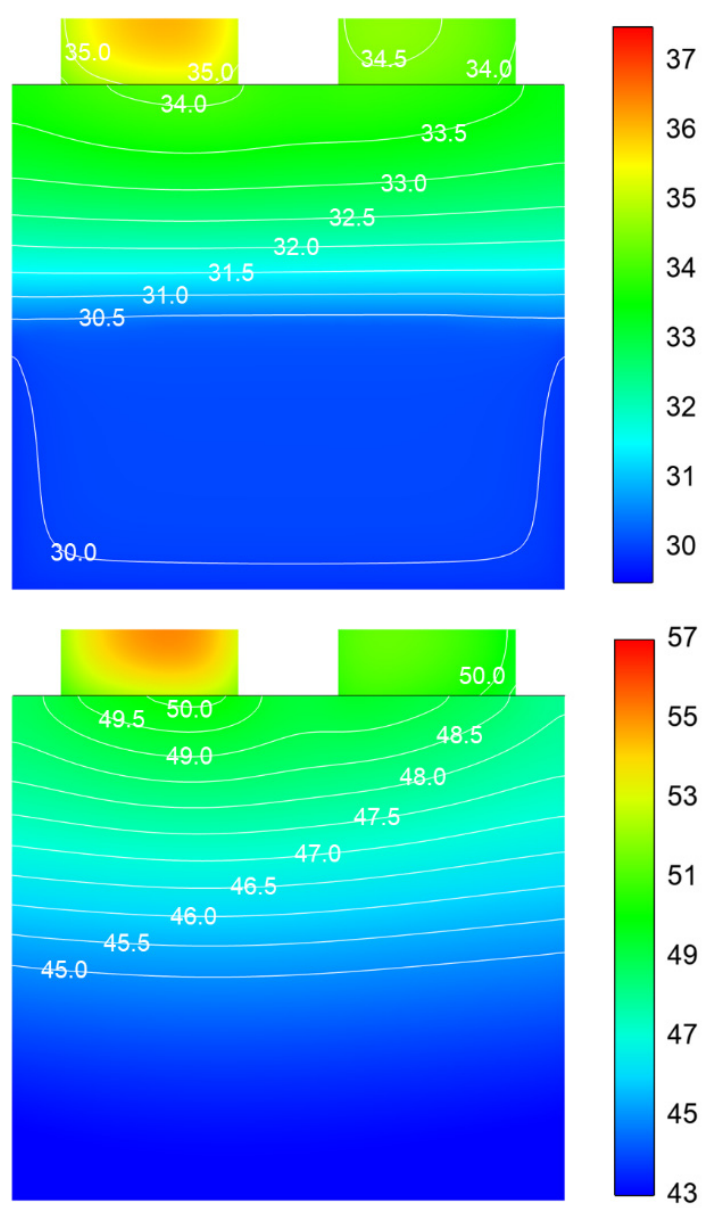

(b)

Figure 16. Contour of temperature on battery surfaces $\left({ }^{\circ} \mathrm{C}\right)$ at the end of discharging: (a) without PCM; (b) with PCM.

Similar trends were observed in the case with the PCM. However, there was a smaller temperature difference at the $3 \mathrm{C}$ as well as the $5 \mathrm{C}$ discharge rates because thermal energy from the battery was absorbed into latent heat. The maximum temperature was located at the negative tab (left tab), which was not cooled by the PCM. For this reason, an active cooling method, such as forced convection, may be necessary. The differences in temperature were $4.5^{\circ} \mathrm{C}$ and $8.2^{\circ} \mathrm{C}$ on the entire battery surface under $3 \mathrm{C}$ and $5 \mathrm{C}$ discharge rates, respectively.

Depending on the amount of heat generated, the PCM can be partly or totally melted. The PCM remained in the mushy zone in the lower region under the $3 C$ discharge rate, while it completely transformed to a liquid state under the $5 \mathrm{C}$ discharge rate.

\section{Conclusions}

A 1D thermal management model of a large-format Li-ion battery (52.3 Ah) with different PCM properties was evaluated. This pouch-type battery was sandwiched between two n-octadecane layers, and the heat generation agreed well with experimental data under both the $3 \mathrm{C}$ and $5 \mathrm{C}$ discharge rates. The diffusion equation that governed the thermal transfer capacity in the PCM was also solved simultaneously. By considering different 
PCM thicknesses and thermal conductivities, a potential model was proposed, which was an assemblage with aluminum foam embedded in n-octadecane. The average conductivity of the resulting enhanced PCM-MF was $2.394 \mathrm{~W} / \mathrm{m} \cdot \mathrm{K}$. The maximum temperature of the Li-ion battery reached $86.8^{\circ} \mathrm{C}$ after $550 \mathrm{~s}$ under the $5 \mathrm{C}$ discharge rate and $64.9^{\circ} \mathrm{C}$ after $900 \mathrm{~s}$ under the $3 \mathrm{C}$ discharge rate without a cooling system. It was shown that the $0.5 \mathrm{~mm}$ thick PCM-MF composite reduced the maximum battery temperature to $49.7^{\circ} \mathrm{C}$ and $33.9^{\circ} \mathrm{C}$ at the $5 \mathrm{C}$ and $3 \mathrm{C}$ discharge rates, respectively.

Then, 3D transient thermodynamic simulations were carried out with an NTGK model using ANSYS Fluent software. Based on comparison with these 3D simulations, we found that the $1 \mathrm{D}$ analysis was capable of accurately estimating the heat dissipation by the PCMMF at the end stage of discharging. The 1D approach clearly produced reliable results in predicting the thermal behavior of the PCM-MF cooling and was superior in practical application terms with its low cost and less time consumption.

Further study on the thermal behavior of active cooling systems with PCMs will be necessary.

Author Contributions: Conceptualization, V.-T.H. and K.C.; methodology, K.C.; software, V.-T.H.; resources, S.-W.L.; writing—original draft preparation, V.-T.H.; writing—review and editing, V.T.H., K.C. and S.-W.L.; supervision, K.C. and S.-W.L.; project administration, K.C. and S.-W.L.; funding acquisition, K.C. and S.-W.L. All authors have read and agreed to the published version of the manuscript.

Funding: This work was supported by Upbringing Business with Innovative Urban Public Institution by the Korean Ministry of Trade, Industry, and Energy (MOTIE) (project name: Establishment of battery/ESS-based energy industry innovation ecosystem) and by the Technology Innovation Program (20006974, "Development of the multi-layered sheets and their forming/joining technologies for the fabrication of $28 \%$ lightweight battery pack/module components of electric vehicles") funded by MOTIE.

Institutional Review Board Statement: Not applicable.

Informed Consent Statement: Not applicable.

Data Availability Statement: Not applicable.

Conflicts of Interest: The authors declare no conflict of interest.

\section{Nomenclature}

\begin{tabular}{|c|c|c|}
\hline$A$ & Surface area $\left(\mathrm{m}^{2}\right)$ & $t$ \\
\hline$A_{1}$ & Correlation constant $(0.35)$ & $T$ \\
\hline c & PCM specific heat $(\mathrm{J} / \mathrm{kg} \cdot \mathrm{K})$ & $T_{a}$ \\
\hline$c_{b}$ & Battery specific capacity $(\mathrm{J} / \mathrm{kg} \cdot \mathrm{K})$ & $T_{b}$ \\
\hline$d$ & PCM thickness (m) & $T_{\text {liquidus }}$ \\
\hline$D O D$ & Depth of discharge (\%) & $T_{\text {solidus }}$ \\
\hline E & Open-circuit voltage $(\mathrm{V})$ & $U$ \\
\hline$H$ & Enthalpy $(\mathrm{J} / \mathrm{kg})$ & $V_{n}$ \\
\hline$I$ & Current (A) & $v$ \\
\hline$j$ & $\begin{array}{l}\text { Volumetric transfer current density } \\
\text { (A) }\end{array}$ & $x$ \\
\hline$k$ & PCM thermal conductivity $(\mathrm{W} / \mathrm{m} \cdot \mathrm{K})$ & $X_{f a}$ \\
\hline$k_{b}$ & $\begin{array}{l}\text { Battery thermal conductivity } \\
(\mathrm{W} / \mathrm{m} \cdot \mathrm{K})\end{array}$ & Greek letters \\
\hline$k_{e f f}$ & $\begin{array}{l}\text { Effective thermal conductivity of } \\
\text { PCM composite }(\mathrm{W} / \mathrm{m} \cdot \mathrm{K})\end{array}$ & $\alpha$ \\
\hline$k_{f}$ & $\begin{array}{l}\text { Thermal conductivity of carbon } \\
(\mathrm{W} / \mathrm{m} \cdot \mathrm{K})\end{array}$ & $\beta$ \\
\hline$k_{l, e f f}$ & $\begin{array}{l}\text { Composite thermal conductivity in } \\
\text { liquid state }(\mathrm{W} / \mathrm{m} \cdot \mathrm{K})\end{array}$ & $\varepsilon$ \\
\hline
\end{tabular}

Time (s)

PCM temperature (K)

Environment temperature $(\mathrm{K})$

Battery temperature $(\mathrm{K})$

Liquidus temperature of PCM

(K)

Solidus temperature of PCM $(\mathrm{K})$

Terminal voltage (V)

Nominal capacity $(\mathrm{V})$

Velocity $(\mathrm{m} / \mathrm{s})$

Distance (m)

Volume ratio of fibers to brush

Thermal diffusivity $\left(\mathrm{m}^{2} / \mathrm{s}\right)$

Liquid fraction

Porosity 


\begin{tabular}{|c|c|c|c|}
\hline$k_{l, P C M}$ & $\begin{array}{l}\text { PCM thermal conductivity in liquid } \\
\text { state }(\mathrm{W} / \mathrm{m} \cdot \mathrm{K})\end{array}$ & $\Delta H$ & Latent heat $(\mathrm{J} / \mathrm{kg})$ \\
\hline$k_{m}$ & $\begin{array}{l}\text { Thermal conductivity of paraffin } \\
(\mathrm{W} / \mathrm{m} \cdot \mathrm{K})\end{array}$ & $\rho$ & PCM density $\left(\mathrm{kg} / \mathrm{m}^{3}\right)$ \\
\hline$k_{s, e f f}$ & $\begin{array}{l}\text { Composite thermal conductivity in } \\
\text { solid state }(\mathrm{W} / \mathrm{m} \cdot \mathrm{K})\end{array}$ & $\rho_{b}$ & Battery density $\left(\mathrm{kg} / \mathrm{m}^{3}\right)$ \\
\hline$k_{s, P C M}$ & $\begin{array}{l}\text { PCM thermal conductivity in solid } \\
\text { state }(\mathrm{W} / \mathrm{m} \cdot \mathrm{K})\end{array}$ & $\sigma_{+}$ & $\begin{array}{l}\text { Effective electric conductivity for } \\
\text { the positive electrode }(1 / \Omega)\end{array}$ \\
\hline$k_{M F}$ & $\begin{array}{l}\text { Metal foam thermal conductivity } \\
(\mathrm{W} / \mathrm{m} \cdot \mathrm{K})\end{array}$ & $\sigma_{-}$ & $\begin{array}{l}\text { Effective electric conductivity for } \\
\text { the negative electrode }(1 / \Omega)\end{array}$ \\
\hline$L$ & Latent heat of material $(\mathrm{J} / \mathrm{kg})$ & $\varphi_{+}$ & $\begin{array}{l}\text { Phase potential of the positive } \\
\text { electrode }(V)\end{array}$ \\
\hline$m_{b}$ & Battery mass $(\mathrm{kg})$ & $\varphi_{-}$ & $\begin{array}{l}\text { Phase potential of the negative } \\
\text { electrode }(V)\end{array}$ \\
\hline$N u$ & Nusselt number & Superscript & \\
\hline $\operatorname{Pr}$ & Prandtl number & $j$ & $\begin{array}{l}\text { Quantity of interest at the } \\
\text { present time level }\end{array}$ \\
\hline$q_{b}$ & Overpotential heat rate $(\mathrm{J} / \mathrm{s})$ & $j+1$ & $\begin{array}{l}\text { Quantity of interest at the new } \\
\text { time level }\end{array}$ \\
\hline$q_{\text {irr }}$ & Irreversible heat rate $(\mathrm{J} / \mathrm{s})$ & Abbreviations & \\
\hline$q_{P C M}$ & Heat rate through PCM $(\mathrm{J} / \mathrm{s})$ & $1 \mathrm{D}$ & One-dimensional \\
\hline$q_{\text {rev }}$ & Reversible heat rate $(\mathrm{J} / \mathrm{s})$ & $3 \mathrm{D}$ & Three-dimensional \\
\hline$Q$ & Discharged battery capacity (Ah) & BTMS & $\begin{array}{l}\text { Battery thermal management } \\
\text { system }\end{array}$ \\
\hline$Q_{0}$ & Fully charged battery capacity (Ah) & C-rate & $\begin{array}{l}\text { A measure of the rate at which a } \\
\text { battery is discharged relative to } \\
\text { its maximum capacity }\end{array}$ \\
\hline$Q_{n}$ & Nominal capacity (Ah) & CFD & Computational fluid dynamics \\
\hline$R$ & Internal resistance $(\Omega)$ & Li-ion & Lithium-ion \\
\hline$R_{\text {cas }}$ & $\begin{array}{l}\text { Thermal resistance of aluminum } \\
\text { case }(\mathrm{K} / \mathrm{W})\end{array}$ & NCM523 & $\mathrm{LiNi}_{0.5} \mathrm{Co}_{0.2} \mathrm{Mn}_{0.3} \mathrm{O}_{2}$ \\
\hline$R_{\text {conv }}$ & $\begin{array}{l}\text { Thermal resistance for convection } \\
(\mathrm{K} / \mathrm{W})\end{array}$ & NTGK & $\begin{array}{l}\text { Newman, Tiedemann, Gu and } \\
\text { Kim }\end{array}$ \\
\hline$R_{\text {int }}$ & Thermal contact resistance $(\mathrm{K} / \mathrm{W})$ & PCM & Phase change material \\
\hline$R a$ & Rayleigh number & PCM-CF & $\begin{array}{l}\text { Phase change material and } \\
\text { carbon fiber }\end{array}$ \\
\hline$S$ & Source term & PCM-EG & $\begin{array}{l}\text { Phase change material and } \\
\text { expanded graphite }\end{array}$ \\
\hline$S O C$ & State of charge $(\%)$ & PCM-MF & $\begin{array}{l}\text { Phase change material and metal } \\
\text { foam }\end{array}$ \\
\hline
\end{tabular}

\section{References}

1. Farag, M.; Sweity, H.; Fleckenstein, M.; Habibi, S. Combined electrochemical, heat generation, and thermal model for large prismatic lithium-ion batteries in real-time applications. J. Power Sources 2017, 360, 618-633. [CrossRef]

2. Pesaran, A.A. Battery thermal models for hybrid vehicle simulations. J. Power Sources 2002, 110, 377-382. [CrossRef]

3. Zhang, H.; Li, C.; Zhang, R.; Lin, Y.; Fang, H. Thermal analysis of a 6s4p Lithium-ion battery pack cooled by cold plates based on a multi-domain modeling framework. Appl. Therm. Eng. 2020, 173, 115216. [CrossRef]

4. Hammami, A.; Raymond, N.; Armand, M. Runaway risk of forming toxic compounds. Nature 2003, 424, 635-636. [CrossRef] [PubMed]

5. Chen, K.; Song, M.; Wei, W.; Wang, S. Design of the structure of battery pack in parallel air-cooled battery thermal management system for cooling efficiency improvement. Int. J. Heat Mass Transf. 2019, 132, 309-321. [CrossRef]

6. Shang, Z.; Qi, H.; Liu, X.; Ouyang, C.; Wang, Y. Structural optimization of lithium-ion battery for improving thermal performance based on a liquid cooling system. Int. J. Heat Mass Transf. 2019, 130, 33-41. [CrossRef]

7. Wang, Z.; Zhang, Z.; Jia, L.; Yang, L. Paraffin and paraffin/aluminum foam composite phase change material heat storage experimental study based on thermal management of Li-ion battery. Appl. Therm. Eng. 2015, 78, 428-436. [CrossRef]

8. Jilte, R.; Afzal, A.; Panchal, S. A novel battery thermal management system using nano-enhanced phase change materials. Energy 2021, 219, 119564. [CrossRef]

9. Putra, N.; Ariantara, B.; Pamungkas, R.A. Experimental investigation on performance of lithium-ion battery thermal management system using flat plate loop heat pipe for electric vehicle application. Appl. Therm. Eng. 2016, 99, 784-789. [CrossRef] 
10. Yang, W.; Zhou, F.; Zhou, H.; Wang, Q.; Kong, J. Thermal performance of cylindrical lithium-ion battery thermal management system integrated with mini-channel liquid cooling and air cooling. Appl. Therm. Eng. 2020, 175, 115331. [CrossRef]

11. Kiani, M.; Ansari, M.; Arshadi, A.A.; Houshfar, E.; Ashjaee, M. Hybrid thermal management of lithium-ion batteries using nanofluid, metal foam, and phase change material: An integrated numerical-experimental approach. J. Therm. Anal. Calorim. 2020, 141, 1703-1715. [CrossRef]

12. Jilte, R.; Afzal, A.; Islam, M.T.; Manokar, A.M. Hybrid cooling of cylindrical battery with liquid channels in phase change material. Int. J. Energy Res. 2021, 45, 11065-11083. [CrossRef]

13. T'Jollyn, I.; Nonneman, J.; Beyne, W.; Paepe, M.D. 1D simulations of thermally buffered prismatic betteries through the application of PCMs. In Proceedings of the 16th International Heat Transfer Conference, Beijing, China, 10-15 August 2018.

14. Greco, A.; Jiang, X.; Cao, D. An investigation of lithium-ion battery thermal management using paraffin/porous-graphite-matrix composite. J. Power Sources 2015, 278, 50-68. [CrossRef]

15. Hallaj, S.A.; Kizilel, R.; Lateef, A.; Sabbah, R.; Farid, M.; Selman, J.R. Passive thermal management using phase change material (PCM) for EV and HEV Li- ion batteries. In Proceedings of the 2005 IEEE Vehicle Power and Propulsion Conference, Chicago, IL, USA, 7-9 September 2005.

16. Hallaj, S.A.; Maleki, H.; Hong, J.S.; Selman, J.R. Thermal modeling and design considerations of lithium-ion batteries. J. Power Sources 1999, 83, 1-8. [CrossRef]

17. Sato, N. Thermal behavior analysis of lithium-ion batteries forelectric and hybrid vehicle. J. Power Sources 2001, 99, 70-77. [CrossRef]

18. Yi, J.; Kim, U.S.; Shin, C.B.; Han, T.; Park, S. Modeling the temperature dependence of the discharge behavior of a lithium-ion battery in low environmental temperature. J. Power Sources 2013, 244, 143-148. [CrossRef]

19. Akeiber, H.; Hosseini, S.; Wahid, M.; Hussen, H.; Mohammad, A. Phase Change Materials-Assisted Heat Flux Reduction: Experiment and Numerical Analysis. Energies 2016, 9, 30. [CrossRef]

20. Fortunato, B.; Camporeale, S.M.; Torresi, M.; Albano, M. Simple mathematical model of a thermal storage with PCM. In Proceedings of the AASRI Conference on Power and Energy Systems, Bari, Italy, 4-5 September 2012.

21. Ambarita, H.; Napitupulu, F.H.; Sitorus, T.B. Numerical study on melting process of phase change material as thermal energy storage. In Proceedings of the 3rd Nommensen International Conference on Technology and Engineering, Medan, Indonesia, 25-26 July 2019.

22. Fleischer, A.S. Thermal Energy Storage Using Phase Change Materials Fundamentals and Applications; Springer: New York, NY, USA, 2015; pp. 37-38.

23. Bernardi, D.; Pawlikowski, E.; Newman, J. A general energy balance for battery systems. J. Electrochem. Soc. 1985, 132, 5-12. [CrossRef]

24. Cengel, Y.A. Heat Transfer: A Practical Approach, 2nd ed.; The McGraw-Hill Companies, Inc.: New York, NY, USA, 2003 ; p. 75.

25. Kim, G.H.; Smith, K.; Lee, K.J.; Santhanagopalan, S.; Pesaran, A. Multi-domain modeling of lithium-ion batteries encompassing multi-physics in varied length scales. J. Electrochem. Soc. 2011, 158, A955. [CrossRef]

26. Ho, V.-T.; Chang, K.; Lee, S.W.; Kim, S.H. Transient thermal analysis of a li-ion battery module for electric cars based on various cooling fan arrangements. Energies 2020, 13, 2387. [CrossRef]

27. Voller, V.R.; Prakash, C. A fixed grid numerical modelling methodology for convection-diffusion mushy region phase-change problems. Int. J. Heat Mass Transf. 1987, 30, 1709-1719. [CrossRef]

28. Javani, N.; Dincer, I.; Naterer, G.F.; Yilbas, B.S. Heat transfer and thermal management with PCMs in a Li-ion battery cell for electric vehicles. Int. J. Heat Mass Transf. 2014, 72, 690-703. [CrossRef]

29. Venkateshwar, K.; Tasnim, S.H.; Simha, H.; Mahmud, S. Influence of metal foam morphology on phase change process under temporal thermal load. Appl. Therm. Eng. 2020, 180, 115874. [CrossRef]

30. Sari, A.; Karaipekli, A. Thermal conductivity and latent heat thermal energy storage characteristics of paraffin/expanded graphite composite as phase change material. Appl. Therm. Eng. 2007, 27, 1271-1277. [CrossRef]

31. Fukai, J.; Hamada, Y.; Morozumi, Y.; Miyatake, O. Effect of carbon-fiber brushes on conductive heat transfer in phase change materials. Int. J. Heat Mass Transf. 2002, 45, 4781-4792. [CrossRef] 